\title{
Effect of energy and protein level in complete feed used elephant grass (Pennisetum purpureum, Schum.) and maize stover (Zea mays. L) silage on nutrient content, total digestible nutrient, and in vitro degradation
}

\author{
Hartutik $^{1^{*}}$, Marjuki ${ }^{1}$, Asri Nurul Huda ${ }^{1}$, and Roi Katul Jannah ${ }^{1}$ \\ ${ }^{1}$ Faculty of Animal Science, University of Brawijaya, Jl. Veteran, Malang 65145, Indonesia
}

\begin{abstract}
The purpose of this research was to determine of ideal ration of energy and protein in complete feed used elephant grass and maize stover silage. The materials were use elephant grass, maize stover silage with $10 \%$ molasses and Lactobacillus plantarum $1 \times 106 \mathrm{CFU} / \mathrm{g}$ and concentrates. The method used experimental laboratory, the data of nutrient and TDN content using descriptive analysis. In vitro degradation value was analysed by Analysis of Variance from a factorial randomized block design and followed by Duncan's Multiple Range Test. The complete feed was use $12.5 \%$ elephant grass $+37.5 \%$ maize stover silage + $50 \%$ concentrates with consist of energy level $(\mathrm{E} 1=12.5$, E2 $=13.5$, E3 $=14.5 \mathrm{MJ} / \mathrm{kg} \mathrm{DM})$ and protein level $(\mathrm{P} 1=10.5, \mathrm{P} 2=13.5, \mathrm{P} 3=16.5 \%)$. The results showed that in vitro DM and OM degradation respectively energy or protein level showed has significantly $(\mathrm{P}<0.01)$, while the interaction did not significant $(\mathrm{P}>0.05)$. The best treatment is E3P3 with energy 14.5 $\mathrm{MJ} / \mathrm{kg}$ and protein $16.5 \%$ on nutrient content DM 92,51\%., OM 90,33\%., CP $16.57 \%$, CF $19.29 \%$, EE $1.77 \%$, NFE $53.70 \%$, TDN content $67.14 \%$, In vitro DM degradation $66.14 \%$ and in vitro $\mathrm{OM}$ degradation $70.01 \%$.
\end{abstract}

\section{Introduction}

Forage as source of fiber is the main feed for ruminants and the fiber to be one of energy source. Elephant grass is a common perennial grass for farmers to be used as fiber source for their livestock. According to Rukmana [1], the nutritional content of elephant grass consists of dry matter $19.9 \%$, crude protein $10.2 \%$, crude fat $1.6 \%$, crude fiber $34.2 \%$, ash $11.7 \%$ and extracts without nitrogen $42.3 \%$. Indonesia has two seasons, namely the rainy and dry seasons, during the rainy season forage will be available in abundance, while in the dry season it is very difficult to obtain so alternative feed is needed for substitution.

*Corresponding author: hartutik@ub.ac.id 
Utilization of feed from agriculture or plantations can be used as a solution to overcome forage supplies and as an effort to reduce environmental pollution, for example, maize stover. In otherwise, the provision of feed for animals is a major contributor to land and water use greenhouse gas emission [5,6]. Maize stover including stems, leaves, flowers and young corn fruit which are generally harvested at the age of 45-65 days contain nutrients, namely, Crude Protein $12.06 \%$, Crude Fiber $25.2 \%$, Ca $0.28 \%$, P 0, 23\% according to Koloud et al [2]. Based on the nutritional quality of maize stover above, it is very necessary to do preservation to maintain its nutritional content as feed, in the long term by using the silage method. Silage is a preservation technology with airtight (anaerobic) conditions that are specially placed, namely silos. Generally, alternative feeds from agriculture have low levels of Water-Soluble Carbohydrate (WSC), according to [3] corn WSC levels reach $11-16 \%$, so additional sources of soluble carbohydrates such as molasses are needed to accelerate the formation of lactic acid which is useful in fermentation.

The addition of lactic acid bacteria can accelerate the ensilage phase to ensure the perfect lactic acid fermentation. Lactic acid bacteria such as Lactobacillus plantarum are producers of lactic acid in the manufacture of silage [4]. In addition to being given feed in the form of forage, ruminants are also given concentrate. Concentrate is feed that is given with the addition of other feeds to increase nutrition by being mixed together as a supplement (complete feed) [4]. Good quality feed has an optimal balance of nutrients for livestock, mainly the energy and protein content in a complete feed. According to Widodo [4] Complete Feed or Total Mixed Ration (TMR) is feed consisting of forage and concentrate in an optimal balance, with the aim of ensuring the intake of nutrients in daily feed so that it is able to supply fiber needs which are very important for stability rumen function. Good feed quality can be seen from the composition of nutrient content through nutrient content analysis which can describe in general the nutrients of feed ingredients. Nutrient content in feed will be useful if the Total Digestible Nutrient is known because in Indonesia it is used as a standard for nutrient substances in feed ingredients. Feed in the rumen will be degraded by rumen microbes, not all nutrient content of feed can be degraded, degradable feed will be used for nutritional needs of rumen microbial activity, this can be done in vitro. In vitro degradation is digestibility that mimics the condition of the body of livestock using laboratory equipment so that it will describe the amount of feed that is degraded in the rumen in vitro using the method from Sjofjan et al [7]. For this reason, further evaluation is needed regarding complete feed using elephant grass and corn silk silage with nutritional balance. Therefore, it is necessary to conduct research on the effect of different energy and protein levels in complete feed using elephant grass and corn husk silage on nutrient content, total digestible nutrient (TDN) and in vitro degradation.

\section{Materials and methods}

\subsection{Materials}

The material used for silage was hybrid maize stover aged 65 days from Sumber Sekar plantation Malang, molasses obtained from animal feed shops and Lactobacilus plantarum obtained from the Wiyasa Mandiri Singosari Laboratory, Malang. The next material was complete feed used 45 days old elephant grass which was obtained from the Sumber Sekar Field Laboratory, Faculty of Animal Husbandry, Universitas Brawijaya Malang. 
Concentrates such as soybean meal, pile, coffee husk and bran were obtained from the animal feed shop Karangploso, Malang. Additional concentrate of "SAE Pujon Concentrate" obtained from Pujon Dairy Cooperative, Malang.

\subsection{Data analysis}

The research data were analysed using a Randomized Block Design (RBD) and continued with Duncan's Multiple Range Test (DMRT). TDN was based on complete feed including energy sources with $\mathrm{CF}>18$ and crude protein content $<20$ with the following calculations. $\mathrm{TDN}(\%)=70.6+0.259 \mathrm{CP}+1.01 \mathrm{EE}-0.76 \mathrm{CF}+0.091 \mathrm{NFE}$

\subsection{Method}

The research method used is a laboratory experiment using descriptive analysis for nutrient content and TDN. The next research method is a laboratory experiment using analysis of variance from a Randomized Block Design (RBD) factorial pattern of two factors, $1^{\text {st }}$ factor (energy level) and $2^{\text {nd }}$ factor (protein level) which were grouped into three groups based on time of rumen fluid collection for degradation analysis. If there is a significant effect on the treatment, it will be continued with Duncan's Multiple Distance Test (DMRT). The Complete feed was added 12.5\% EG (Elephant Grass) and 37.5\% MS (Maize Stover Silage) with $50 \%$ concentrate. The metabolizable energy (ME) content of concentrate was a) $12.5 \mathrm{MJ} / \mathrm{kg} \mathrm{DM}$, b) $13.5 \mathrm{MJ} / \mathrm{kg} \mathrm{DM}$, c) $14.5 \mathrm{MJ} / \mathrm{kg}$ DM and the level of protein content $10.5 \%, 13.5 \%, 16.5 \%$. The combination and composition of the treatment are as follows:

Table 1. Combination and composition of the treatment

\begin{tabular}{|c|c|c|c|}
\hline $\begin{array}{l}\text { Energy } \\
(\mathrm{Mj} / \mathrm{kg})\end{array}$ & $\begin{array}{c}\text { Protein } \\
(\%)\end{array}$ & Code & Description \\
\hline \multirow{3}{*}{$\begin{array}{c}\text { E1 } \\
(12.5)\end{array}$} & $\begin{array}{c}\mathrm{P} 1 \\
(10.5)\end{array}$ & E1P1 & $\begin{array}{c}12.5 \% \text { EG }+37.5 \% \mathrm{MSS}+50 \% \text { Concentrate } \\
\text { (Energy } 12.5 \mathrm{MJ} / \mathrm{kg} \text { dan Protein } 10.5 \% \text { ) }\end{array}$ \\
\hline & $\begin{array}{c}\mathrm{P} 2 \\
(13.5)\end{array}$ & E1P2 & $\begin{array}{c}12.5 \% \mathrm{EG}+37.5 \% \mathrm{MSS}+50 \% \text { Concentrate } \\
(\text { Energy } 12.5 \mathrm{MJ} / \mathrm{kg} \text { dan Protein } 13.5 \%)\end{array}$ \\
\hline & $\begin{array}{c}\mathrm{P} 3 \\
(16.5)\end{array}$ & E1P3 & $\begin{array}{l}12.5 \% \text { EG }+37.5 \% \mathrm{MSS}+50 \% \text { Concentrate } \\
(\text { Energy } 12.5 \mathrm{MJ} / \mathrm{kg} \text { dan Protein } 16,5 \%)\end{array}$ \\
\hline \multirow{3}{*}{$\begin{array}{c}\text { E2 } \\
(13.5)\end{array}$} & $\begin{array}{c}\mathrm{P} 1 \\
(10.5)\end{array}$ & E2P1 & $\begin{array}{l}12.5 \% \text { EG }+37.5 \% \mathrm{MSS}+50 \% \text { Concentrate } \\
(\text { Energy } 13.5 \mathrm{MJ} / \mathrm{kg} \text { dan Protein } 10.5 \%)\end{array}$ \\
\hline & $\begin{array}{c}\mathrm{P} 2 \\
(13.5)\end{array}$ & E2P2 & $\begin{array}{c}12.5 \% \text { EG }+37.5 \% \mathrm{MSS}+50 \% \text { Concentrate } \\
(\text { Energy } 13.5 \mathrm{MJ} / \mathrm{kg} \text { dan Protein } 13.5 \%)\end{array}$ \\
\hline & $\begin{array}{c}\mathrm{P} 3 \\
(16.5)\end{array}$ & E2P3 & $\begin{array}{c}12.5 \% \mathrm{EG}+37.5 \% \mathrm{MSS}+50 \% \text { Concentrate } \\
(\text { Energy } 13.5 \mathrm{MJ} / \mathrm{kg} \text { dan Protein } 16.5 \%)\end{array}$ \\
\hline \multirow{3}{*}{$\begin{array}{c}\text { E3 } \\
(14.5)\end{array}$} & $\begin{array}{c}\mathrm{P} 1 \\
(10.5)\end{array}$ & E3P1 & $\begin{array}{c}12.5 \% \text { EG }+37.5 \% \mathrm{MSS}+50 \% \text { Concentrate } \\
(\text { Energy } 14.5 \mathrm{MJ} / \mathrm{kg} \text { dan Protein } 10.5 \%)\end{array}$ \\
\hline & $\begin{array}{c}\mathrm{P} 2 \\
(13.5)\end{array}$ & E3P2 & $\begin{array}{l}12.5 \% \text { EG }+37.5 \% \mathrm{MSS}+50 \% \text { Concentrate } \\
(\text { Energy } 14.5 \mathrm{MJ} / \mathrm{kg} \text { dan Protein } 13.5 \%)\end{array}$ \\
\hline & $\begin{array}{c}\mathrm{P} 3 \\
(16.5)\end{array}$ & E3P3 & $\begin{array}{c}12.5 \% \mathrm{EG}+37.5 \% \mathrm{MSS}+50 \% \text { Concentrate } \\
(\text { Energy } 14.5 \mathrm{MJ} / \mathrm{kg} \text { dan Protein } 16.5 \%)\end{array}$ \\
\hline
\end{tabular}

$\mathrm{EG}=$ Elephant grass; MSS = Maize Stover Silage 
Table 2. Chemical Composition of Raw Materials

\begin{tabular}{|c|c|c|c|c|c|c|c|c|c|}
\hline \multirow{2}{*}{ Raw material } & \multicolumn{7}{|c|}{ Chemical Composition (\%DM ) } \\
\cline { 3 - 10 } & & $\mathbf{D M}$ & $\mathbf{O M}$ & $\mathbf{A s h}$ & $\mathbf{C P}$ & $\mathbf{E E}$ & $\mathbf{C F}$ & NFE & TDN \\
\hline 1 & $\begin{array}{c}\text { SAE Pujon } \\
\text { Concentrate }\end{array}$ & 97.60 & 90.06 & 9.94 & 18.38 & 4.70 & 14.97 & 52.00 & 70.18 \\
\hline 2 & Elephant grass & 96.12 & 85.95 & 14.05 & 12.08 & 2.35 & 31.99 & 39.54 & 55.39 \\
\hline 3 & Silage 14 days & 94.54 & 89.36 & 10.64 & 7.8 & 0.94 & 22.45 & 58.17 & 61.81 \\
\hline 4 & Soybean Meal & 93.53 & 91.62 & 8.38 & 47.53 & 2.57 & 4.04 & 37.48 & 80.68 \\
\hline 5 & Coffee husk & 94.14 & 89.42 & 10.58 & 10.11 & 1.49 & 34 & 43.82 & 52.87 \\
\hline 6 & Bran & 90.63 & 87.40 & 12.60 & 10.15 & 13 & 16.20 & 48.06 & 71.43 \\
\hline 7. & Pile & 92.59 & 82.87 & 17.13 & 1.76 & 0.44 & 25.39 & 55.28 & 57.24 \\
\hline
\end{tabular}

Information

*) The results of the analysis at the Laboratory of Nutrition and Animal Feed, Faculty of Animal Science, Universitas Brawijaya (2021)

*) $\mathrm{DM}=$ Dry Matter $\mathrm{OM}=$ Organic Matter $\mathrm{CP}=$ Crude Protein $\mathrm{EE}=$ Ether Extract $\mathrm{CF}=$ Crude Fiber NFE $=$ Nitrogen Free Extract TDN $=$ Total Digestible Nutrient

Table 3. Feed Formulation

\begin{tabular}{|c|c|c|c|c|c|c|c|c|c|c|}
\hline $\begin{array}{c}\text { Energy } \\
\text { Level } \\
(\mathrm{MJ} / \mathbf{k g})\end{array}$ & $\begin{array}{c}\text { Protein } \\
\text { Level } \\
(\%)\end{array}$ & Code & $\begin{array}{c}\text { MSS } \\
(\%)\end{array}$ & $\begin{array}{l}\text { EG } \\
(\%)\end{array}$ & $\begin{array}{l}\text { SPC } \\
(\%)\end{array}$ & $\begin{array}{c}\text { Bran } \\
(\%)\end{array}$ & $\begin{array}{l}\text { Pile } \\
(\%)\end{array}$ & $\begin{array}{c}\text { SBM } \\
(\%)\end{array}$ & $\begin{array}{l}\text { CH } \\
(\%)\end{array}$ & $\begin{array}{c}\text { Total } \\
\text { (g/DM) }\end{array}$ \\
\hline \multirow{3}{*}{$\begin{array}{c}\text { E1 } \\
(12.5)\end{array}$} & P1 (10.5) & E1P1 & 37.5 & 12.5 & 18 & 12 & 4.5 & - & 15.5 & 100 \\
\hline & P2 (13.5) & E1P2 & 37.5 & 12.5 & 23 & 7 & - & 5.5 & 14.5 & 100 \\
\hline & P3 (16.5) & E1P3 & 37.5 & 12.5 & 18 & - & - & 14.5 & 17.5 & 100 \\
\hline \multirow{3}{*}{$\begin{array}{c}\text { E2 } \\
(13.5)\end{array}$} & P1 (10.5) & E2P1 & 37.5 & 12.5 & 24 & 6 & 11.5 & - & 8.5 & 100 \\
\hline & P2 (13.5) & E2P2 & 37.5 & 12.5 & 50 & - & - & - & - & 100 \\
\hline & P3 (16.5) & E2P3 & 37.5 & 12.5 & 36.5 & - & 2.3 & 11.2 & - & 100 \\
\hline \multirow{3}{*}{$\begin{array}{c}\text { E3 } \\
(14.5)\end{array}$} & P1 (10.5) & E3P1 & 37.5 & 12.5 & 30 & - & 19.5 & 0.5 & - & 100 \\
\hline & P2 (13.5) & E3P2 & 37.5 & 12.5 & 23 & - & 17.6 & 9.4 & - & 100 \\
\hline & P3 (16.5) & E3P3 & 37.5 & 12.5 & 13.5 & - & 17 & 19.5 & - & 100 \\
\hline
\end{tabular}

MSS: Maize Stover Silage; EG: Elephant grass; SPC: SAE Pujon Concentrate; RB: Rice

Bran; SBM: Soyabean Meal; CFH: Coffee Husk 


\section{Result and Discussion}

\subsection{Chemical Composition Profile}

The quality of feedstuff is reflected on its chemical composition, higher content of nutritive value better quality of feedstuff. The complete feed chemical composition is presented in Table 3. Based on the chemical composition analysis of complete feed using elephant grass, maize stover silage with different energy and protein balances, showing differences in nutritional content, it because each treatment contains more than one concentrate with different nutrients and compositions that cause different chemical composition. In addition, the differences in nutrient quality may be due to the difference feed manufacturers, as well as the quality of raw materials and difference processes. The DM content in complete feeds with the highest different energy and protein balances was 93.09\% in E2P3 (Energy 13.5 $\mathrm{MJ} / \mathrm{kg}+$ Protein $16.5 \%$ ).

Dry matter consists of organic matter and ash while organic matter consists of $\mathrm{CP}, \mathrm{CF}$, $\mathrm{EE}$ and NFE. The higher the CP content, the dry matter content can increase Riswandi, et al. [8]. The OM content in E3P3 (Energy $14.5 \mathrm{MJ} / \mathrm{kg}$ + Protein 16.5\%) had the highest OM content of all energy and protein balance treatments, which was $90.33 \%$. According to Riswandi, et al. [8] high organic matter content of other nutrients such as CP, CF, EE, NFE, nitrogen and vitamins are also high. According to Rukmana [1] the content of organic matter is a substance in feed ingredients that is related to other components such as dry matter and ash. The highest fat content in E2P2 (Energy $13.5 \mathrm{MJ} / \mathrm{kg}+$ Protein $13.5 \%$ ) is $3.14 \%$, this is presumably due to the use of $50 \%$ concentrate in the ration, while the EE content in SAE Pujon concentrate is high $4.70 \%$. Ether Extract contains some dietary fat, namely triglycerides which are commonly found in grains, high fat content in feed has a negative effect on dry matter digestibility of feed. The type of fat that affects digestibility is saturated fat which can reduce the digestibility of dry matter, organic matter, NDF (fiber) in the rumen, the higher the fat content in the feed, the lower the digestibility [9].

The content of CF E1P3 (Energy $12.5 \mathrm{MJ} / \mathrm{kg}$ + Protein 16.5\%) has a low crude fiber content of $18.15 \%$ this is due to the use of concentrated feed ingredients in the amount of $18 \mathrm{~g} / \mathrm{DM}$, soybean meal $14.5 \mathrm{~g} / \mathrm{DM}$ and coffee husk $17.5 \mathrm{~g} / \mathrm{DM}$. Crude fiber is composed of cellulose (polysaccharide), lignin and hemicellulose which functions as a protective plant cell wall. Low CF content does not necessarily mean high digestibility, CF with high lignin content makes feed difficult to digest. R. Rukmana [1] stated that CF is difficult to digest due to the cellulose, hemicellulose, and lignin content in the cell wall. The NFE content in E3P2 (Energy $14.5 \mathrm{MJ} / \mathrm{kg}$ + Protein 13.5\%) is the highest value among all energy and protein balance treatments. This is presumably due to the high use of feed ingredients such as SAE Pujon concentrate and cassava bagasse because both feed ingredients are high in NFE content. According to Budiman et al. [7], the increasing of protein content affects the absorption and nutrient content of feed, so NFE can increase. Sutowo et al. [10] stated that the increase of NFE contributes to the increase the digestibility of dry matter, organic matter and TDN. 
Table 4. The Average value of the chemical composition of complete feed consist of elephant grass, maize stover silage with a balance of energy and protein

\begin{tabular}{|c|c|c|c|c|c|}
\hline \multirow{2}{*}{$\begin{array}{c}\text { Chemical } \\
\text { Composition } \\
\text { (\%DM) }\end{array}$} & \multicolumn{5}{|c|}{ Protein Level (\%) } \\
\hline & $\begin{array}{c}\text { Energy } \\
\text { Level } \\
\text { (MJ/kg) }\end{array}$ & $P_{1}(10.5)$ & $P_{2}(13.5)$ & $P_{3}(14.5)$ & Average \\
\hline \multirow{4}{*}{$\mathrm{DM}$} & E1 (12.5) & 92.93 & 92.70 & 92.72 & 92.78 \\
\hline & E2 (13.5) & 92.26 & 92.37 & 93.09 & 92.57 \\
\hline & E3 (14.5) & 92.15 & 93.07 & 92.51 & 92.58 \\
\hline & Average & 92.45 & 92.71 & 92.77 & \\
\hline \multirow{4}{*}{$\mathrm{OM}$} & E1 (12.5) & 88.18 & 88.52 & 89.21 & 88.64 \\
\hline & E2 (13.5) & 89.16 & 88.06 & 88.75 & 88.65 \\
\hline & E3 (14.5) & 89.86 & 90.21 & 90.33 & 90.13 \\
\hline & Average & 89.06 & 88.93 & 89.43 & \\
\hline \multirow{4}{*}{ Ash } & E1 (12.5) & 11.83 & 11.48 & 10.79 & 11.37 \\
\hline & E2 (13.5) & 10.84 & 11.94 & 11.25 & 11.34 \\
\hline & E3 (14.5) & 10.14 & 9.79 & 9.67 & 9.86 \\
\hline & Average & 10.94 & 11.07 & 10.57 & \\
\hline \multirow{4}{*}{$\mathrm{CP}$} & E1 (12.5) & 10,51 & 13.37 & 16.55 & 13.48 \\
\hline & E2 (13.5) & 10.74 & 13.49 & 16.73 & 13.65 \\
\hline & E3 (14.5) & 10.55 & 13.24 & 16.57 & 13.45 \\
\hline & Average & 10.6 & 13.37 & 16.62 & \\
\hline \multirow{4}{*}{$\mathrm{EE}$} & E1 (12.5) & 2.83 & 2.77 & 2.32 & 2.64 \\
\hline & E2 (13.5) & 2.87 & 3.14 & 2.48 & 2.83 \\
\hline & E3 (14.5) & 2.28 & 2.24 & 1.77 & 2.09 \\
\hline & Average & 2.66 & 2.72 & 2.19 & \\
\hline \multirow{4}{*}{$\mathrm{CF}$} & E1 (12.5) & 22.73 & 21.22 & 18.15 & 20.7 \\
\hline & E2 (13.5) & 22.40 & 19.62 & 19.18 & 20.4 \\
\hline & E3 (14.5) & 21.45 & 18.75 & 19.29 & 19.83 \\
\hline & Average & 22.19 & 19.86 & 18.87 & \\
\hline
\end{tabular}




\begin{tabular}{|c|c|c|c|c|c|}
\hline \multirow{2}{*}{$\begin{array}{c}\text { Chemical } \\
\text { Composition } \\
\text { (\%DM) }\end{array}$} & \multicolumn{5}{|c|}{ Protein Level (\%) } \\
\hline & $\begin{array}{c}\text { Energy } \\
\text { Level } \\
\text { (MJ/kg) }\end{array}$ & $P_{1}(10.5)$ & $P_{2}(13.5)$ & $P_{3}(14.5)$ & Average \\
\hline \multirow{4}{*}{ NFE } & E1 (12.5) & 52.09 & 51.17 & 52.19 & 51.82 \\
\hline & E2 (13.5) & 53.15 & 51.81 & 50.36 & 51.77 \\
\hline & E3 (14.5) & 55.58 & 55.98 & 53.70 & 55.09 \\
\hline & Average & 53.61 & 52.99 & 52.08 & \\
\hline
\end{tabular}

Information : *) The results of the analysis at the Laboratory of Nutrition and Animal Feed, Faculty of Animal Science, Universitas Brawijaya (2021).

\subsection{Nutrient degradability profile}

Table 5. TDN content of complete feed of elephant grass, maize stover silage with different energy and protein balances

\begin{tabular}{|c|c|c|c|c|}
\hline \multicolumn{5}{|c|}{ TDN (\%DM) } \\
\hline \multirow{2}{*}{$\begin{array}{c}\text { Energy Level } \\
\text { (MJ/kg) }\end{array}$} & \multicolumn{3}{|c|}{ Protein Level (\%) } & \multirow[t]{2}{*}{ Average } \\
\hline & P1 (10.5) & P2 (13.5) & P3 (16.5) & \\
\hline E1 (12.5) & 63.30 & 65.16 & 67.81 & 65.42 \\
\hline E2 (13.5) & 63.61 & 66.67 & 67.15 & 65.81 \\
\hline E3 (14.5) & 63.65 & 66.37 & 67.14 & 65.72 \\
\hline Average & 63.42 & 66.06 & 67.36 & \\
\hline
\end{tabular}

Information: *) The results of the analysis at the Laboratory of Nutrition and Animal Feed, Faculty of Animal Science, Universitas Brawijaya (2020)

The higher the TDN value, the better the quality of the feed ingredients. E1P3 (Energy 12.5 $\mathrm{MJ} / \mathrm{kg}$ + Protein $16.5 \%$ ) showed the highest TDN value among all treatments, this was due to the high protein content of the feed ingredient, namely soybean meal. The high TDN is assumed due to the contribution of CP, EE, CF and NFE, so that the nutrients in the feed are easily digested. TDN describes the total energy in the feed consumed by livestock. The TDN value depends on the digestibility of organic matter, such as crude protein, crude fiber, ether extract and NFE [11]. TDN can be determined from the chemical composition of digested CP, EE, CF and NFE. According to Indah et al [12] TDN content will increase if the OM, CP and EE content increases, while TDN will decrease if the content of CF and fiber fractions such as ADF, NDF, lignin, cellulose and hemicellulose increases. 
Table 6. Dry Matter Degradation (DMD) Value (\%) used elephant grass, maize stover silage with different energy and protein balances.

\begin{tabular}{|c|c|c|c|c|}
\hline \multirow{2}{*}{ Energy level } & \multicolumn{3}{|c|}{ Dry Matter Degradation (\%) } & \multirow{2}{*}{ Average } \\
\cline { 2 - 4 } & P1 (10.5) & P2 (13.5) & P3 (16.5) & \\
\cline { 2 - 4 } & 46.05 & 51.66 & 61.21 & $53.88^{\mathrm{a}}$ \\
\hline $\mathrm{E}_{1}(12.5)$ & 53.34 & 55.49 & 63.33 & $56.74^{\mathrm{b}}$ \\
\hline $\mathrm{E}_{2}(13.5)$ & 62.26 & 63.07 & 66.14 & $63.56^{\mathrm{c}}$ \\
\hline $\mathrm{E}_{3}(14.5)$ & $53.88^{\mathrm{a}}$ & $56.74^{\mathrm{ab}}$ & $63.56^{\mathrm{b}}$ & \\
\hline Average & & &
\end{tabular}

Information: a-c) Different superscripts in the same row and column show a very significant effect $(P<0.01)$ on DMD

Table 7. Organic Matter Degradation (OMD) Value (\%) used elephant grass, maize stover silage with different energy and protein balances.

\begin{tabular}{|c|c|c|c|c|}
\hline \multirow{2}{*}{ Energy Level } & \multicolumn{3}{|c|}{ Organic Matter Degradation (\%) } & \multirow{2}{*}{ Average } \\
\cline { 2 - 4 } & P1 (10.5) & P2 (13.5) & P3 (16.5) & \\
\cline { 2 - 4 } & 52.92 & 58.79 & 65.06 & $58.23^{\mathrm{a}}$ \\
\hline E1 (12.5) & 58.07 & 57.79 & 63.65 & $60.81^{\mathrm{ab}}$ \\
\hline E2 (13.5) & 63.70 & 65.84 & 70.01 & $66.24^{\mathrm{b}}$ \\
\hline E3 (14.5) & $58.92^{\mathrm{a}}$ & $59.84^{\mathrm{a}}$ & $66.52^{\mathrm{b}}$ & \\
\hline Average & & & \multicolumn{3}{|c|}{} \\
\hline
\end{tabular}

Information: a-c) Different superscripts in the same row and column show a very significant effect $(<0.01)$ on OMD

The results of the analysis of variance DMD and OMD combinations of different energy and protein balances did not show any interaction $(\mathrm{P}>0.05)$, but in respectively treatment with an increase in energy or protein levels, there are high significant effect $(\mathrm{P}<0.01) . \mathrm{E}_{3} \mathrm{P}_{3}$ (Energy $14.5 \mathrm{MJ} / \mathrm{kg}+$ Protein 16.5\%) showed the highest dry matter degradation value $66.14 \%$. It can be concluded that with the addition of energy and protein levels will produce a high degradation value. It because the increase of feed balance, good quality of feedstuffs. According to Noorsati et al [14] the factors that affect dry matter digestibility are composition of feed ingredients, $\mathrm{pH}$, good temperature, or air quality (aerobic/anaerobic), rumen fluid, buffer solution, sample particle size, and incubation time. The CF content is also very influential on dry matter digestibility, the lower CF in the feed will increase digestibility. It because the high fiber content causes the cell walls to become thick, so the feed is difficult to degrade. Dewi et al [15] Added that lignocellulose is the main component of cell walls consisting of hemicellulose, cellulose, lignin, and several other extractive ingredients that bind strongly to inhibit the digestibility of feed nutrients.

The highest organic matter degradation value was in E3P3 (Energy $14.5 \mathrm{MJ} / \mathrm{kg}+$ Protein $16.5 \%$ ) of $70.01 \%$. This is presumably due to the influence of the energy and protein levels given, the higher the energy and protein levels can increase the digestibility 
of organic matter. According to Noorsati et al [14] degradation of organic matter is influenced by silica and lignin contained in cell walls which together form complex compounds with hemicellulose and cellulose. This compound is difficult to penetrate by enzymes from rumen microbes so that it will reduce digestibility and cell contents including organic matter. According to Dewi et al [15] the OMD value was higher than the DMD value, this was because the dry matter still contained of ash, while the organic matter no longer contained of ash. Ash in the feed causes slow feed degradation therefore organic matter without ash is easier to digest by rumen microbes. If in the analysis there is a decrease in OMD, it is suspected that the microbes in the rumen have had sufficient nutrition, so they are not able to utilize feed which has an impact on decreasing the performance of rumen microbes. Crude protein content is very influential on digestibility.

\section{Conclusion}

The results showed that a complete feed with energy of $14.5 \mathrm{MJ} / \mathrm{kg}$ and protein $16.5 \%$ was the best treatment with a nutrient content value of DM 92.51\%, OM 90.33\%, Ash 9.67\% CP 16.57 , CF $19.29 \%$, EE $1.77 \%$ and NFE $53.70 \%$ and the TDN content is $67.14 \%$. The content of DMD is $66.14 \%$ and OMD is $70.01 \%$, so it can be concluded that feed with 14.5 $\mathrm{MJ} / \mathrm{kg}$ of energy and $16.5 \%$ protein can meet the needs of livestock.

\section{References}

1. R. Rukmana, Budi Daya Rumput Unggul (Penerbit Kanisius, Yogyakarta, 2005)

2. A. Koloud, C.L. Kaunang., A.V. tuturoong, M.R. Waani, Zootech 40, 428-438 (2020)

3. T. Naibaho, Despal, Permana, I.G, Buletin Makanan Ternak 104, 12-20 (2007)

4. D.S. Widodo, Pengaruh lama fermentasi dan penambahan inokulum Lactobacillus plantarum dan Lactobacillus fermentum terhadap kualitas silase tebon jagung (Zea mays, Malang, Indonesia, 2014)

5. D. N. Adli, Liverstock Research Rural Development 33, 10 (2021)

6. O. Sjofjan, D. N. Adli, M.H. Natsir, Y. F. Nuningtyas, T. S. Wardani, I. Sholichatunnisa, S. N. Ulpah, O. Firmansyah, Jurnal Ilmu Ternak dan Veteriner 26, 3948 (2021)

7. A. Budiman, T. Dhalika, B. Ayuningsih. Jurnal Ilmu Ternak 6, 132-135 (2006)

8. Riswandi, Muhakka, M. Lehan, Jurnal Peternakan Sriwijaya 4, 35-46 (2015)

9. K.J. Harvatine, Allen MS, Journal of Dairy Science 88, 4018-4027 (2005)

10. I.T. Sutowo, Adelina, D. Febrina, Jurnal Peternakan 12, 41-47 (2016)

11. M. Mastopan, Tafsin, N. D. Hanafi, Jurnal Peternakan Integratif 3, 37-45 (2014)

12. A. Indah, I. G. Permana, Despal, Sains Peternakan 18, 38-43 (2020)

13. Kusmartono, Marjuki, Jurnal Ilmu-Ilmu Peternakan 24, 8-9 (2014)

14. M. Noorsati, L. K. Nuswantara, A. Subrata, Animal Agriculture Journal 1, 143-158 (2012)

15. O. Dewi, Suryani, I. M. Mudita, E-journal Peternakan Tropika 8, 587-605 (2020) 